\title{
Comparative Analysis of Regional Service Trade Competitiveness Indexes - A Study Based on the Service Trade Innovation Development Pilot
}

\author{
Hong $\mathrm{Li}^{\mathrm{a}}$ and Lizi Chen ${ }^{\mathrm{b}, *}$ \\ School of Management, Tianjin University of Technology, Tianjin 300384, China \\ a1347324676@qq.com, bchenlizi999@163.com \\ Corresponding author: Lizi Chen
}

Keywords: Service Trade, Competitiveness index, Pilot cities.

\begin{abstract}
With the rapid growth of the service industry, service trade has become a "new engine" to promote economic growth in a country or region. The level of competitiveness of trade in services is gradually becoming a key indicator of the international competitiveness of a country or region. Tianjin and Shanghai as the most important port city and Service Trade Innovation Development Pilot cities, the level of its service trade competitiveness is related to the overall competitiveness of China's trade level. Therefore, based on this background, this paper makes a comparative evaluation of the competitiveness of service trade in Tianjin and Shanghai by constructing TC, RCA and STO index analysis system.
\end{abstract}

\section{Introduction}

In recent years, the global service trade is growing fast, its growth rate of about 3 to 5 times the rate of trade in goods, trade in services has become a new engine of global free trade.In 2016, the growth rate of China's service trade was about $27.02 \%$, while the growth rate of trade in goods over the same period was only $1.27 \%$. Service trade in China has been developed rapidly, but on the whole international competitiveness is relatively insufficient, and is still "short board" of foreign trade.In February 2016, the State Council promulgated the "Reply to the Pilot Project on Agreed Development of Innovative Development of Service Trade". It decided to carry out pilot projects on innovation and development of service trade in 15 districts such as Tianjin and Shanghai, and promote the structural reform of supply side in service trade.

\section{Literature References}

Scholars at home and abroad for service trade competitiveness extensively studied from different angles, to measure service trade competitiveness index can be divided into two categories. The first type is absolute indicators, such as the International Market Share (IMS). Shuhua Zhao and Zheng Song (2006) selected four indicators of total import and export, international market share, import and export industry structure and trade competition index, which measured the competitiveness of Beijing's service trade and concluded that the development of service trade in Beijing ranks the forefront of the country but the advantages are relatively weak. The other is the relative index, such as the Revealed Comparative Advantages Index (RCA index), Trade Competitive Advantage Index (TC index), and Comparative Competitive Advantage Index (CA index). Gary Hufbauer (2007) used the RCA index to analyze the total volume and internal structure of trade in India. It believed that although the total trade advantage of India was not significant, it was more competitive. Yi Huang (2011) evaluates the development of service trade in Sichuan Province from four dimensions: RCA index, TC index, CA index and service trade dependency. The conclusion is that tourism, construction, installation, labor contracting services, computer and information services are the mainly development areas in Sichuan province. Hu Bin and Hu Jing (2015) compared the competitiveness of service trade in Shanghai, Hong Kong and Singapore. The index of export factors selected IMS, export contribution 
rate and TC index. The index of import factors was RCA index, It is concluded that the competitiveness of Shanghai's service trade is still weak compared with that of Hong Kong and Singapore, and the competitiveness of service trade in Hong Kong and Singapore is relatively stable.

In general, the research has been mainly based on specific regions or macro-regions, and there are few literatures on comparative studies on trade in services between provinces and cities. This article selects Shanghai and Tianjin as the research object, from the multiple perspectives analysis development level and competitiveness of service trade.

\section{Total services trade and structural analysis}

\subsection{Analysis on the Scale of Service Trade}

From the trend point of view, Tianjin and Shanghai service trade development scale continues to expand, growth is also significantly accelerated. As can be seen from Table 1, the import of Tianjin's services trade in 2006 was US $\$ 4.23$ billion, increasing to US $\$ 10.69$ billion by 2015 , and the scale of export increased from US \$ 3.18 billion in 2006 to US \$ 12.78 billion in 2015. In 2010, under the influence of the World Expo effect, the total import and export volume of Shanghai's service trade increased by $40.06 \%$, and the scale was over 100 billion US dollars, which ushered in the development of trade services billion times. At present, the volume of Shanghai's services trade has been close to one-third of the country, indicating that service trade has not only become the engine of Shanghai's economic structural transformation, but also has played a prominent role in the global resource allocation function Domestic and foreign market integration of the development of functional hub.

Table 1. The amount of import and export (Unit: one hundred million dollars)

\begin{tabular}{|c|c|c|c|c|c|c|}
\hline \multirow{2}{*}{ Year } & \multicolumn{2}{|c|}{ Tianjin } & \multicolumn{2}{c|}{ Shanghai } & \multicolumn{2}{c|}{ China } \\
\cline { 2 - 7 } & Export & Import & Export & Import & Export & Import \\
\hline 2006 & 31.8 & 42.3 & 192.7 & 210.7 & 914.0 & 1003.0 \\
\hline 2007 & 51.4 & 58.7 & 250.7 & 308.4 & 1217.0 & 1293.0 \\
\hline 2008 & 41.3 & 78.7 & 345.5 & 390.2 & 1464.0 & 1580.0 \\
\hline 2009 & 55.8 & 88.3 & 299.6 & 447.7 & 1286.0 & 1581.0 \\
\hline 2010 & 60.3 & 98.4 & 406.8 & 639.9 & 1702.0 & 1922.0 \\
\hline 2011 & 69.5 & 76.6 & 473.5 & 819.2 & 1821.0 & 2370.0 \\
\hline 2012 & 77.4 & 79.9 & 516.0 & 999.6 & 1904.0 & 2801.0 \\
\hline 2013 & 80.8 & 103.5 & 596.0 & 1129.4 & 2106.0 & 3291.0 \\
\hline 2014 & 112.2 & 111.0 & 493.3 & 1260.6 & 2222.0 & 3821.0 \\
\hline 2015 & 127.8 & 106.9 & 418.4 & 1548.3 & 2299.0 & 4364.0 \\
\hline
\end{tabular}

Source: Tianjin data from the Tianjin Bureau of Statistics, Shanghai data calculated from the relevant Data, the national data from the Ministry of Commerce.

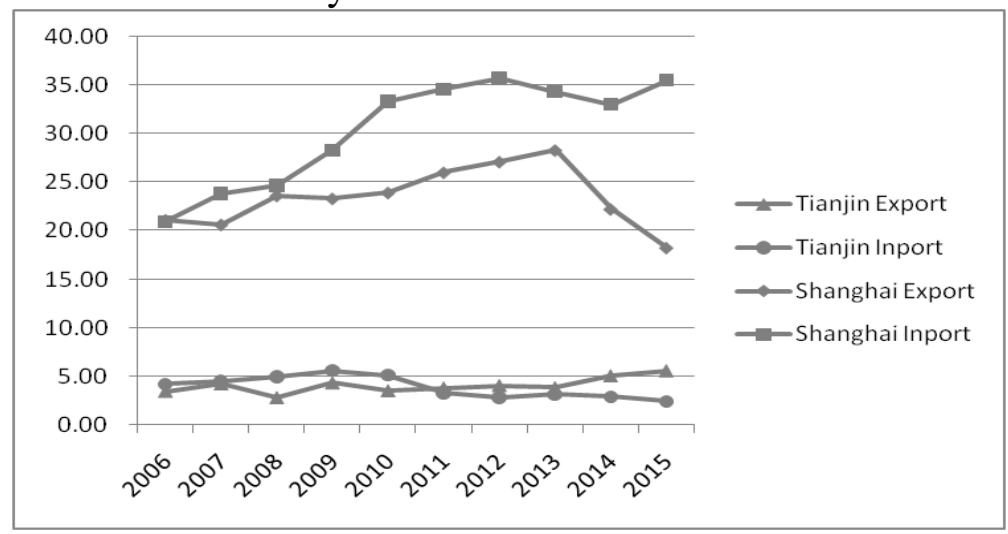

Fig.1 The percentage of import and export service trade in Tianjin and Shanghai accounted in China

\subsection{Analysis of Service Trade Structure}

Shanghai service trade import and export scale continued to expand, but also accompanied by the expansion of the trade deficit. Table 1 shows that imports of service trade in Shanghai increased from 
US \$ 21.07 billion to US \$ 154.83 billion in 2006-2015, with annual growth rate of more than $60 \%$ and exports increasing from US \$ 19.27 billion to US \$ 41.84 billion, with an average annual growth rate about $10 \%$, the difference in the growth rate of import and export of services, led to the expansion of the trade deficit. On the contrary, Tianjin's trade deficit is gradually narrowing, and even nearly two years has emerged a trade surplus trend, Tianjin Port as the largest port city in the north, relying on the positive development of trade in goods, the formation of a variety of trade in services development. Until now, Tianjin service trade has included transportation, tourism, foreign contracting and labor cooperation, finance, computer and information, consulting and other industries. With the continuous emphasis on the status of service trade in Tianjin and the strong investment in services trade, Tianjin will also achieve greater development of trade in services.

\section{Comparison of Regional Service Trade Competitiveness Index}

Based on the existing research, this paper chooses TC index, RCA index and STO index to calculate the change of service trade index in Tianjin and Shanghai from 2006 to 2015, and carries out specific price evaluation on the competitiveness of service trade in 2 cities.

\subsection{Introduction to the index}

\subsubsection{TC Index}

The TC index is the trade specialization index, which refers to the ratio of the difference between the import and export and its total import and export. The index is an important indicator of the international competitiveness of China's service trade. Its greatest advantage is that it can avoid the impact of inflation, As well as the impact of large differences in imports and exports between countries.

$$
T C_{i j}=\left(X_{i j}-M_{i j}\right)\left(X_{i j}+M_{i j}\right)
$$

Where $X_{\mathrm{ij}}$ represents the export, and $\mathrm{M}_{\mathrm{ij}}$ represents the imports, which ranging from -1 to 1 .

\subsubsection{RCA Index}

The RCA index is a comparative advantage index, which eliminates the influence of the total amount of the country and the volatility of the world. It can better reflect the comparative advantage of the export of an industry and the average export level of the world.

$$
\boldsymbol{R C} \boldsymbol{A}_{i j}=\boldsymbol{X}_{i j} / \boldsymbol{X}_{i} / \boldsymbol{X}_{w_{j}} / \boldsymbol{X}_{w}
$$

Where $X_{i j}$ represents the exports of $j$ goods in country $i, X_{i}$ represents the total exports in country $i$, $X_{w j}$ represents the exports $j$ goods in global, $X_{w}$ represents the total global exports.It is generally believed that if the RCA index is greater than 2.5, it indicates that the industry is strongly competitive; if the RCA index is between 1.25 and 2.5 , it indicates that the industry is highly competitive; if the RCA index is between 0.8 and 1.25 , Indicating that the industry is moderately competitive; if the RCA index is less than 0.8 , then the export product industry competitiveness is weak.

\subsubsection{STO Index}

The STO Index is the Openness Index of Service Trade, which is used to measure the degree of openness of service trade in a country or region, reflecting the contribution of the level of service trade to its gross domestic product (GDP).

$$
S T O=\left(S_{x}+S_{m}\right) / G D P
$$

Where Sx and Sm represent regional trade in services exports and imports respectively. The higher the STO index, the higher the degree of openness to its service trade. 


\subsection{Conclusion and suggestion}

Table 1. Comparison of Competitiveness Index

\begin{tabular}{|c|c|c|c|c|c|c|c|c|c|}
\hline \multirow{2}{*}{ Year } & \multicolumn{3}{|c|}{ Tianjin } & \multicolumn{3}{c|}{ Shanghai } & \multicolumn{3}{c|}{ China } \\
\cline { 2 - 11 } & TC Index & RCAIndex & STO Index & TC Index & RCAIndex & STOIndex & TC Index & RCAIndex & STO Index \\
\hline 2006 & -0.142 & 0.45 & 13.23 & -0.045 & 0.32 & 30.42 & -0.046 & 0.402 & 7.02 \\
\hline 2007 & -0.066 & 0.38 & 15.94 & -0.103 & 0.36 & 34.03 & -0.030 & 0.409 & 7.12 \\
\hline 2008 & -0.312 & 0.42 & 12.40 & -0.061 & 0.42 & 36.32 & -0.038 & 0.429 & 6.67 \\
\hline 2009 & -0.226 & 0.49 & 13.08 & -0.198 & 0.40 & 33.93 & -0.103 & 0.386 & 5.67 \\
\hline 2010 & -0.240 & 0.48 & 11.64 & -0.223 & 0.45 & 41.28 & -0.061 & 0.454 & 6.00 \\
\hline 2011 & -0.049 & 0.57 & 8.35 & -0.267 & 0.47 & 43.50 & -0.131 & 0.436 & 5.59 \\
\hline 2012 & -0.016 & 0.50 & 7.70 & -0.319 & 0.46 & 47.41 & -0.191 & 0.431 & 5.56 \\
\hline 2013 & -0.123 & 0.61 & 7.90 & -0.309 & 0.54 & 48.98 & -0.220 & 0.419 & 5.68 \\
\hline 2014 & 0.005 & 0.68 & 8.72 & -0.437 & 0.91 & 45.71 & -0.265 & 0.369 & 5.84 \\
\hline 2015 & 0.089 & 0.67 & 8.84 & -0.575 & 0.93 & 49.08 & -0.310 & 0.351 & 6.06 \\
\hline
\end{tabular}

RCA index only consider the export factors. Although the RCA index of Shanghai service trade increased year by year, but most of them are ranged $0-0.8$, indicating that the competitiveness of Shanghai's services trade is still not strong enough. In 2014 its RCA index is 0.91, For the first time more than 0.8 , indicating that its competitiveness gradually strengthened; China's overall RCA index is low, and in recent years there is a downward trend; TC index in addition to consider the export factor, also takes into account the import factor. Shanghai and the national service trade TC index are negative, and showing a deteriorating trend, indicating that the Shanghai service trade is not only weak international competitiveness, and the deficit is also expanding. While the TC index of Tianjin service trade gradually changed from negative to positive, indicating that its international competitiveness position is relatively stable.

\section{References}

[1]. Shuhua Zhao, Zheng Song. An Analysis of International Competitiveness of Beijing's Service Trade [J].Exploring Economic Problems. Feb. 2006(02), p. 26-30.

[2]. Gary Hufbauer, Sherry Stephenson. Services Trade past Liberalization and Future Challenge [J], Journal of International Economic Law. 2007(03), p. 605-630.

[3]. Yi Huang. Analysis on the Competitiveness of Service Trade in Sichuan [J].International trade issues. 2012(01),p.119-130,

[4]. Bin Hu, Jing Hu. International Competitiveness of Shanghai's Service Trade Development in Open Transformation: Comparison and revelation [J]. City observation, 2015(06). 